\title{
ETT FÄNGELSE I FÄNGELSET
}

\author{
Av MatTi TuOVinen
}

Om det faller på en läkares lott att verka som läkare i ett krig, innebär en framgångsrik verksamhet under sådana omständigheter inte nödvändigtvis att vederbörande godkänner kriget eller ställer sig på dess sida. På motsvarande sätt innebär det faktum, att man verkar som fängelseläkare, nödvändigtvis inte att man godkänner den straffideologi som upprätthåller fängelseväsendet. Såsom en konkret realitet som omger vårt arbete, som en ram, som omsluter oss och fångarna, måsta vi likväl förstå och i någon mån kunna acceptera fängelsesystemet. I våra förhållanden är det lätt för en fängelseläkare att undgå kriminalpolitiska ställningstaganden, eftersom man i dessa sammanhang enligt finsk tradition aldrig ens frågar efter psykiaternas synpunkter. Den relativt stränga, och beträffande reformtakten mycket konservativa, strafflagen samt det rätt höga fångtalet innehar $\mathrm{i}$ vår kultur en traditionellt stark ställning.

Under decennierna efter kriget har utvecklingen inom vissa samhällssektorer i ekonomiskt och socialt hänseende framskridit i rask nordisk takt. Utgående från denna synvinkel kunde man vänta sig, att kriminalpolitiken med sin konkreta samhälleliga representation skulle ha blivit delaktig av en bredare samhällsdiskussion. Den principiella och verkligt omfattande diskussionen har dock varit mycket ringa. Diskussionen har snarast inskränkt sig till kortvariga "raseriutbrott« på olika nivåer förorsakade av uppseendeväckande brott. Utgående från denna rätt ålderdomliga tradition är t.o.m. mycket små progressiva framskridanden värdefulla i våra förhållanden. Som ett dylikt drag kan man uppmärksamma den ökande oron över isoleringsfenomenet, som uppstått inom fängelseväsendet. Man har konstaterat att isoleringen, särskilt i slutna fängelser för långtidsfångar, har en tendens at öka. Isoleringen kan leda till att vissa delar av anstalten eller vissa funktioner »slammar igen«, precis på samma sätt som en elakartad växt kan påverka moderorganismen när den tillåts utvecklas enligt sina egna lagar utan att ta notis om den övriga organismen.

På samma sätt som fängelset jämfört med det övriga samhället, beträffande vissa sociala, gruppsykologiska och individualpsykologiska processer är en primitiv och arkaistisk samhällets bakgård, kan det även inom fängelset uppstå en verksamhetssektor, inom vilken situationerna i mångt och mycket verkar att styras av mycket elementära processer.

Min avsikt är inte att nalkas den överdrivna isoleringensproblematik från juridiskt-administrativa synpunkter. Tvärtom försöker jag bli vid min läst som 
psykiater. Kanske jag dock till en början skall ge vissa ramuppgifter. Det dagliga fångtalet är i vårt land ca 4.500-4.800. Den genomsnittliga tiden i fängelset är ca ett halvt år. Det årliga intaget av fångar är alltså ca 10.000. Beträffande isoleringsproblemen har vi fäst uppmärksamhet vid långtidsisoleringen och problematiken kring denna. En fånge kan placeras i enrum som disciplinstraff på grund av ordningsförseelse eller för den tid man undersöker en disciplinförseelse. För en kort tid kan en fånge tillfälligt placeras i enrum för att förhindra rymning eller för att stävja våldsamhet. Dessutom har man varit tvungen att placera fångar i enrum på deras egen begäran, på grund av fruktan för den egna säkerheten, eller när man har haft anledning att misstänka att fången utgör ett hot mot de övriga făngarnas säkerhet eller mot anstaltens säkerhet. För att utreda de i lagstiftningen ingående grunderna för de sistnämnda placeringarna tillsattes i augusti 1982 en arbetsgrupp som hade till uppgift att utreda reformbehovet och göra förslag till åtgärder beträffande stadgandena om straffảngars isolering. Denna arbetsgrupp, som kallades enrumsarbetsgruppen, föreslog i sitt betänkande på våren 1983 vissa lagändringar, i vilka man har preciserat, samlat och givit lagstatus åt vissa stadganden.

För FN:s kriminalpolitiska institut i Helsingfors (HEUNI) har isoleringsproblemet undersökts av Matti Joutsen (Matti Joutsen: Solitary confinement and administrative segregation in Finnish Prisons, HEUNI 1983). Under första halvåret 1982 användes isolering som disciplinstraff 875 gånger i Finlands fängelser. Enligt en undersökning som omfattade genomsnittet för en dag fanns det 12.8.1982 i fängelserna 211 personer, som var isolerade från de övriga fångarna. På grund av säkerhetsorsaker eller som disciplinstraff var 105 fảngar isolerade, 106 fångar var placerade i enrum på egen begäran. De som fått ett disciplinstraff för överträdelse mot fängelseordningen var isolerade under en relativt kort tid; den längsta isoleringen av denna orsak var 15 dagar. Den mest problematiska gruppen utgjordes likväl av dem, som var isolerade på grund av rymningsbenägenhet eller våldsamhet samt dem, som själv hade krävt att bli placerade $\mathrm{i}$ enrum på grund av rädsla. Beträffande dessa kan isoleringen i vissa fall räcka t.o.m. i åratal.

\section{Om mentalhygienen}

Ofta konstaterar man helt allmänt, att isolering i fängelse i och för sig förorsakar mentalhygieniska problem. Detta är ju alldeles uppenbart, då frihetsstraffet innebär en genomgripande livsförändring beträffande de sociala relationerna och objektrelationerna samt beträffande de mekanismer som upprätthåller självkänslan och den individuella driftekonomin. Personlighetens mest utvecklade funktioner kräver för att upprätthållas en regelbunden möjlighet till en maksimalt utvecklad växelverkan med yttervärlden. Om denna går förlorad, 
sker det en regression. Beträffande många sociala funktioner, såsom kärlekslivet och andra viktiga objektrelationer, kan en individ inte i ett slutet fängelse fungera till fullo. I detta avseende är det i sig själv en kris att hamna i fängelse.

Det är överraskande hur litet frågan om initialreaktionerna vid en intagning $\mathrm{i}$ fängelse har betonats $\mathrm{i}$ isoleringsdiskussionen. Kanske beror detta på, att för mångas del den intensiva förstareaktionen har upplevts redan under det eventuellt långvariga anhållningsskedet. Anhållande kan ju hos oss $\mathrm{i}$ Finland vara $3+14$ dagar. Ur en fängelsepsykiaters synvinkel förundrar man sig likväl trots detta, ibland över, att det inkommer relativt få fall av akuta fängelscinställelsekriser för vård från länsfängelserna. Som extrema exempel kan här nämnas delirium-fallen, av en vilka en mycket stor del behandlas i länsfängelserna utan hjälp från specialenheten. Beträffande de svåraste förstareaktionerna verkar det som om åtminstone länsfängelsernas omsorgsförmåga skulla vara effektiv.

Det mentalhygieniska problemet består egentligen inte ännu i det, att frihetsberövandet innefattar en förlust av vissa värdefulla levnadsfunktioner. Krisens symptomatik definieras egentligen först av, hurudan kompensations- och anpassningskapacitet vederbörande har. Frågan gäller hurudan han primärt är till sin personlighet med avseende på sin sociala förmåga, sina människorelationer och sitt driftsliv. Min erfarenhet som fängelsepsykiater begränsar sig till den grupp fångar, som sökt sig till eller blivit överförda till psykiatrisk vård. I denna grupp är andelen våldsbrottslingar större än bland fångarna $\mathrm{i}$ allmänhet. Dessa är också socialt sett den hjälplösaste delen av fångarna. I allmänhet kan man beträffande fångarna konstatera, att de har lägre utbildningsnivå än normalbefolkningen och andelen ogifta och frånskilda är klart högre än bland normalbefolkningen. Dylika allmänt deskriptiva faktorer ger redan en vink om svåra utvecklingsdefekter, som man upptäcker då man gör undersökningar på individuell nivå. Kunde man då inte säga, att en fängelsevistelse inte utgör någon egentlig kris för en person, eftersom han inte förlorar något värdefullt som en gång uppnåtts? I vissa fall kan man utgående från mentalhygieniska erfarenheter faktiskt påstå detta. Det finns t.ex. alkoholister, vilkas levnadssätt tidvis antar självmordsmässiga former, varför fångenskapsperioderna de facto räddar dem till livet. Allmänt taget kan likväl tragiken tillspetsas i påståendet, att sådana som minst tål det hamnar i fängelse. Personer som har en begränsad social förmåga har svårare att hitta kompenserande medel. En person, vars självkänsla är skör och lätt regredierar till sina primitiva former, stöder sig i fängelset på de antisociala gruppidentifikationer, som erbjuds eller så förlorar han annars kontakten med sin egen personlighet. För en individ som har en benägenhet att ta till våld utgör en situation, där våldsamheten begränsas med externa medel, en hotande situation. $\AA$ ena sidan tvingar en sådan situation personligheten att 
söka sig i riktning mot mer utvecklade driftsutlösningar, å andra sidan i riktning mot självdestruktion, som t.ex. självmord.

Endel forskare understryker, att det för en psykopatisk personlighet är förmånligt och terapeutiskt utvecklande att bli föremål för begränsningar och yttre kontroll. Fängelsevistelsen i sig själv lär dem likväl ingenting, eftersom det ofta är just de s.k. psykopatiska personligheterna som saknar introspektionsförmåga. För att de verkligen utvecklingsmässigt skulle kunna utnyttja situationen, borde introspektionsundervisning stå till buds, d.v.s. professionella resurser för psykologiskt arbete tillsammans med dem.

Det mentalhygieniska problemet är alltså en fråga om en anpassningskris, om inre alternativ som väckts av isoleringssituationen, om utvecklingsmöjligheter eller om brist på sådana. I detta avseende innebär alltså en fängelsevistelse att livssituationen och det sociala fältet inskränks och primitiviseras. En särskild belastning för personligheten utgörs därutöver av en fortsatt isolering i form av fullständig ensamhet. I dylika fall antar bristen på insitament och avsaknaden av stimulans redan sådana mått, att t.o.m. neurofysiologiska undersökningssynpunkter har relevans. Sålunda har man i dessa fall observerat specifika EEG-förändringar samt förändringar i hudens förmåga att leda elektricitet. Vissa neurologer är av den åsikten, att under förhållanden med total brist på stimulans skulle det mycket fort uppstå t.o.m. irreversibla förändringar på neurofysiologisk nivå. Det är uppenbart att regressionen även på upplevelsenivån kan vara rätt dramatisk. Detta kan konstateras med rätt enkla experimentella undersökningar eller denna faktor kan ingå t.ex. i en vanlig seglares erfarenhet: efter att i flera timmar ha spanat in i mörkret kan dramatiska illusioner eller synhallucinationer tona fram utan att dessa likväl har samma personliga symptomvärde som t.ex. i samband med en psykotisk kris. Om den yttre stimulansen saknas, medför en slags homeostas att den bristande stimulansen ersätts med inre perceptioner. Under speciella förhållanden är det rätt allmänt att hos fångarna uppstår hörselvillor, och inom fängelsepsykiatrin lär man sig snart, att symptomvärdet av detta fenomen bland de isolerade är mindre alarmerande än då hörselvillor uppstår när den yttre situationen är mera normal. En hallucination hos en isolerad är i sig själv inte det mest alarmerande fenomenet, snarare pekar det på att det finns en kompensationspotential. Det mest alarmerande är en vidsträckt känslolöshet och apati. Ifråga om observationerna är det mest alarmerande alltså inte förekomsten av eventuella illusoriska felobservationer, utan att observationsfältet i allmänhet inskränks och att reaktionerna utarmas. Många isolerade beskriver detta som en hot om en tilltagande avtrubbning, men hos somliga är observationsförmågan ifråga om den egna personen så outvecklad, att förändringen förblir oregistrerad, eller så har orsaken till att man velat bli isolerad just varit en strävan att komma in i ett tillstånd av apati, i en hibernation. 
I sinnessjukhuset för făngar, d.v.s. den enhet som jag representerar, behandlas årligen ca 300 patienter. Hos ca $30 \%$ är störningen på psykosnivå. Hos endel har den psykotiska krisen brutit ut i samband med isolering. Hos endel kan man märka att de sökt isolering i ett försök att rädda sig från en psykotisk kris, som trots detta kontrollförsök sedan ända brutit ut.

Då isoleringen eller den självvalda avskiljdheten uppnår ett visst mått, börjar det sociala tomrum och stimulanstomrum som uppstått utlösa självdestruktiva processer och regressionsfenomen i făngens personlighet. Största delen av de finländska fångar, som är internerade i tvångsinrättning är personer, beträffande vilka man tidigare, t.ex. under det skede då de var föremål för sinnesundersökning, kunnat ana, att det i deras personlighet döljer sig en i själva verket psykotisk kärna, fastän de enligt påföljdsrekommendationerna inte ansetts vara sinnessjuka. Med tiden börjar sedan, tack vare tvångsinrättningens erosionsinverkan, de primitiva projektionsmekanismerna och de psykotiska dragen tona fram och förorsakar till slut t.o.m. redan kliniskt sett akuta episoder av sinnesjukdom. Beträffande vissa patienter har denna utveckling, förutom en synnerlig farlighet, med en sensationell sannolikhet kunnat förutspås. I dessa bedömningar har alltså frågan om det är samhället eller individen som skall skyddas, kunnat vara till ytterlighet understruken.

\section{Om växelverkan}

Redan då jag skisserade upp isoleringsproblemets formella ramar framgick det, att det vid isolering är fråga om anstaltens reaktioner på en fånges uppförande/beteende. Här är likväl fråga om två parter. Kunde det möjligen vara så att det $\mathrm{i}$ anstalten, och också hos personalen, fïnns sådana faktorer, som i samma riktning kan verka »igenslammande« på anstalten som de faktorer, vilka härstammar från fångarna? Till sitt innersta psykologiska väsen är dessa faktorer på båda sidor säkert mycket nära varandra, eftersom både fảngarna och vakterna är människor. Det är säkert viktigt och i anstaltens intresse att man vid rekryteringen försöker se till, att personer som har benägenhet för våld eller utpräglat paranoida drag inte söker sig till făngvården. Förutom fängelsepersonalens individuella drag och vissa grupprocesser i olika anstalter inverkar också frågor om makt i organisationen starkt på detta område. Fängelsesystemet är av tradition till sin uppbyggnad rätt auktoritärt. Därför blir frågan om behandlingen av făngarna lätt ett instrument, som används endast som ett maktmedel. Det är väl bekant i den psykiatriska anstaltserfarenheten, att internernas eller patienternas psykopatologi överraskande långt formar anstalten och organisationen; t.o.m. till sådana delar, som vanligtvis anses vara rent administrativa, formella processer vilka kan isoleras från de övriga människorelationerna. Det är möjligt, att inom fångvårdsväsendet rädslan för primitiva affekter kan nå 
fram t.o.m. till administrativa konflikter och förstelna dem. Det att denna rädsla når fram är inte ett särskilt överraskande fenomen, om vi betänker, hur stor mängd primitivt raseri systemet måste resorbera.

Vad skulle man då ur psykiatrisk synvinkel kunna rekommendera i denna trängda situation, i detta spänningsfält för primitiva krafter? För att en växelverkan $\mathrm{i}$ anstaltslivet skulle ha en uppbyggande funktion, borde man däri införa möjligheter till mottaglighet och positiv empati, som i någon mån även tillåter aggressiva utlopp. En person vars självkänsla är på ett primitivt sätt strukturellt skadad, kan i ett växelverkansförhållande mottaga någonting endast då han eller hon känner sig ge eller ha gett någonting. Denna strävan efter en ställning som givare tar sig ibland rätt klumpiga och egocentriska uttryck präglade av egoism, varför det inte är så lätt att komma underfund med givandets natur bland dessa drag. Men om personalen är mottaglig och gör noggranna observationer, kan denna insikt märkbart förbättra umgänget. Det är i ett finländskt fängelse alltjämt viktigt att man värdesätter och framhäver det arbete, som fången utför. Jag betonar inte detta på grund av arbetets ekonomiska eller moraliska värde, utan som en nödvändighet för växelverkan. De, som passivt endast girigt kräver något, kan inte på något vis ta emot eller utnyttja det som erbjuds dem. Jag anser att en viktig del av anstaltens funktioner är, att man vaksamt gör iakttagelser av fångarna och anstaltens interna relationer och man fortgående analyserar dessa iakttagelser.

En dylik fortgående undersökning är inte någon särskilt tacksam uppgift av den orsaken, att kunskapen skall kunna användas för att förändra svåra personligheter eller för att verkligen utreda de psykiska störningarna. Kunskap ger alltså inte makt, men den ger ofta en möjlighet till sådana förändringar $\mathrm{i}$ umgänget, som trots att de verkar skenbara kan vara synnerligen värdefulla. En analyserad kunskap om, hur svåra personlighetsstörningar vi sist och slutligen har att göra med, ökar förstås känslan av mänsklig tragedi i arbetet, men hjälper å andra sidan till att inrikta arbetet på de delmål, som trots allt är möjliga att nå och vilkas uppnående gynnas av den ökande kunskapen. Misströstan och kapitulationsstämningar i detta arbete kan nämligen också de bottna i storhetsvansinne beträffande målen. Det är viktigt, att växelverkan och upprätthållandet av kontakter i sig själva anses vara värdefulla och att man till detta vågar foga reseptivt mod. Underställd ett projektivt tryck är personalen i fångvårdsarbetet lätt benägen att känna sig själv ond och värdelös. Detta kan med destruktiva följder sprida sig till hela yrkeskårens självrespekt. Ett fortgående arbete i syfte att eliminera denna fara hjälper kanske till att upprätthålla den uppfattningen, att också denna känsla är ett motöverföringsproblem som hör till yrket.

För ca ett år sedan skedde i min egen anstalt för första gången i dess historia 
den första utbrytningen med användning av våld, som utfördes av sex fångar tillsammans. För anstalten var det inte ett så stort problem att bevakningen slog fel, utan problemet var de efterdyningar för anstaltsprocessen som händelsen skapade. Fastän det var fråga om en personal som erhållit utbildning i vårdyrket, var kravet på vapen och en våldsam hämndmentalitet mycket överraskande, och de samfällda paranoida fantasierna häpnadsväckande bjärta. Först nu över ett år senare kan man verkligen nalkas saken i form av en dialog. En fortgående analyserande dialog är en av de viktigaste medlen att minska på spärrar och kommunikationsstockningar i anstalten.

Fastän mitt föredrag behandlar ett mänskligt problem på individnivå, är det också fråga om en rätt direkt koppling till egenskaper hos vårt samhälle. Det problem som vi här penetrerat kan i väsentlig grad härledas ur vårt outvecklade påföljdssystem. Ett mångsidigare påföljdssystem skulle minska på trycket från dessa primitiviseringstendenser, också fastän de nya påföljdsalternativen inte direkt skulle beröra den mest problematiska delen av internerna, kring vilka isoleringsproblemet uppstår.

Alternativen skulle ha en viktig betydelse också för fångvårdsväsendet: det skulle vara skäl att utöka antalet specialiserade fängelseavdelningar. Det har också redan varit tal om att grunda en narkotikafri avdelning. Man kunde även tänka sig en psykoterapiavdelning för psykoterapeutisk vård av noggrannt utvalda långtidsfångar och för personalens utbildning. Om man i fängelsepsykiatriska sammanhang ställer som mål för vårdverksamheten att verkligen eftersträva strukturella förändringar i internernas personlighet, är det fråga om ett mycket svårt, riskfyllt arbete på lång sikt som kräver hög utbildning. Att placera tyngdpunkten inom den psykoterapeutiska verksamheten på dylika mål är diskutabelt. Men om man genom verksamheten och utbildningen fattar, hur omfattande social hjälplöshet det egentligen gäller när vi talar om våldsbenägna personer så kunde de mänskliga resurserna användas effektivare och på ett för bägge parterna mer givande sätt.

För att synpunkterna i dessa frågor skall bli en fortgående del av dialogen $\mathrm{i}$ anstalterna, är det viktigt att utveckla personalens utbildning och arbetshandledning både inom ramen för grupp- och individuell verksamhet.

Då år 1984 nu inleds påminns vi om den mänskliga utarmning som beskrivs av Orwell. De mest drastiska farorna i denna process kan beskådas just i fängelset, men där kan samtidigt också ses utmaningen att lösa upp denna process.

Adresse: Överläkare Matti Tuovinen

Sinnessjukhuset för făngar

PB 357, SF - 20101 Åbo, Finland. 